\title{
Participatory Budgeting: A Comparative Study of Croatia, Poland and Slovakia
}

\author{
Jasmina Džinić1, Mária Murray Svidroňová ${ }^{2}$, Ewa Markowska-Bzducha ${ }^{3}$
}

\begin{abstract}
The New Public Management movement regards citizens as customers and, accordingly, focuses on the quality of services provided by public-sector organizations. Since this approach negatively affected democratic values, there has been a shift of the focus from consumer satisfaction and quality of services to quality of governance. The latter implies the improvement of the relationship between government and citizens as active members of the community. Over the last twenty years, participatory budgeting $(\mathrm{PB})$ has become a popular form of co-production intended to improve the quality of local governance. The aim of the article is to provide a comparative analysis of the use and role of PB in Croatia, Poland and Slovakia and to identify the models of PB used in selected countries. In order to compare the case studies of municipalities in selected countries, a qualitative analysis has been used and the classification of PB models applied. Most analyzed local units use the "Porto Alegre adapted for Europe" model, but the "Consultation on public finances", "Representation of Organized Interest" and "Proximity participation" models are also represented. The main findings are that PB indeed enables better allocation of public sources according to citizens' needs (various public services were delivered following the trend of social innovation and co-creation), but the problem lies in the low amount assigned for $\mathrm{PB}$ from public budgets and the relatively low interest of citizens to participate in the $\mathrm{PB}$ processes. $\mathrm{PB}$ might also bring certain risks linked with its implementation, e.g. misuse of the idea for political reasons or additional costs of projects delivered in the PB process.
\end{abstract}

1 Faculty of Law, University of Zagrebv, Zagreb, Croatia, E-mail: jdzinic@pravo.hr

2 Department of Public Economics and Regional Development, Matej Bel University in Banska Bystrica, Banska Bystrica, Slovakia, E-mail: maria.murraysvidronova@umb.sk

3 Department of Regional Development and Quantitative Methods, Kazimierz Pulaski University of Technology and Humanities in Radom, Radom, Poland, E-mail: ewabz@poczta.onet.pl 


\section{Key words:}

public services, governance, participatory budgeting, citizens, Croatia, Poland, Slovakia

\section{Introduction}

A major feature of the New Public Management (NPM) is the introduction of various private-sector mechanisms in the running of public-sector organizations. Although having some positive aspects, the NPM approach has proved to be a narrow one. Citizens are more and more obliged to pay full price for the services provided/managed by public-sector organizations (Kozuń-Cieślak 2013; Nemec et al. 2012). Their position has been almost equal to one of the customers obtaining the services within the private sector. In accordance with this new relationship between the public-sector organizations and their customers, exceeding customer satisfaction has become the new understanding of the quality concept (Bovaird and Löfler 2003 , 138). However, responsiveness and quality of services are not the only values contemporary public administration (PA) should follow. They should be broadened with other goals and values inherent to the role of PA and the public sector in general. Similarly, in their relation with administrative organizations citizens should play different roles, including that of PA's partner. This idea lies in the concept of "governance", often specified with additional attributes such as "collaborative", "participatory", "open", etc. According to this approach, the government is not considered the dominant institution, and the steering of society is carried out through networks and partnerships between governments, business corporations and civil-society organizations (Pollitt and Bouckaert 2011). The governance/good-governance concepts are new approaches to the management of public administration reflecting changes in the provision of public services, and as such they are the subject of many researchers. The concept of governance is defined as the sum of interactions, where there is a cooperation of actors from the public and private sectors in solving social problems (Osborne and Brown 2005) and it is aimed at the improvement of public administration (Klimovský 2010).

However, the concept of governance is not unambiguous, and a number of alternative, sometimes even contradictory meanings can be found in the literature (Pierre and Peters 2005). Rhodes (1996) indicates six different uses of the term "public governance", referring to: the minimal state; corporate governance; the new public management; "good governance"; socio-cybernetic systems; and self-organizing networks. By analyzing the new approach to service delivery in Britain, he regards governance as "self-organizing, interorganizational networks" complementing hierarchies and markets as traditional means of coordination. Osborne (2006 and 2010) differentiates three broad schools of governance literature: corporative governance, "good" governance and public governance, where the latter is further divided into 
socio-political governance, public-policy governance, administrative, contract governance and network governance. Dunleavy et al. (2006) have developed a special model of governance entitled "Digital-Era Governance". The definition of governance given by Bovaird and Löfler $(2002,16)$ seems the most appropriate to encompass the meaning of governance without determining the relationship among different stakeholders in advance. They define governance as "the set of formal and informal rules, structures and processes which define the ways in which individuals and organisations can exercise power over the decisions (by other stakeholders) which affect their welfare and quality of life."

In the spirit of the above-mentioned definition of good governance, one such solution for its implementation can be participatory budgeting $(\mathrm{PB})$, which is being analyzed in three countries, namely Croatia, Poland and Slovakia. The aim of this paper is to provide a comparative analysis of the use and role of $\mathrm{PB}$ in selected countries and to identify the models of $\mathrm{PB}$ used. In doing so, the aim is first of all to fill in the gap on the empirical evidence of PB use in Eastern European countries and secondly, to specify the strengths and weaknesses of identified PB models as well as to recommend further steps in a better adaptation of $\mathrm{PB}$ in post-communist countries.

\section{Participatory budgeting - a theoretical framework}

PB has been one of the most successful participatory instruments of the past 15 years (Sintomer et al. 2008). It was introduced for the first time in Porto Alegre in Brazil in 1989. Nowadays, PB is becoming more and more popular in Europe, as well. It is being introduced by local governments in many countries, such as the UK, France, Germany, Italy and Spain (Wampler 2013). So far, approximately 3,000 local communities acquired the idea of citizens' involvement in decision-making on how to spend public financial resources.

It is quite problematic to define what $\mathrm{PB}$ is, especially when the conditions and forms of citizen participation in the budget-allocation procedure in Europe are very different from those in Latin America. According to the UN the essence of PB can be defined as a mechanism through which the population decides on, or contributes to decisions made on, the destination of all or part of the available public resources at the local level (UN-HABITAT 2004).

The way in which these instruments will work depends on the authorities and residents of individual municipalities. They are responsible for how the participatory budgets will affect local communities. Despite the existing risks, PB is now considered one of the most effective instruments to increase citizen participation in local community affairs, providing citizens the possibility to make a real impact (Sintomer et al. 2008). 
Sintomer et al. (2008) distinguish several models of PB:

- Porto Alegre adapted for Europe represents a break with traditional devices of participation. Discussions in neighbourhood and/or thematic assemblies primarily deal with concrete investments and projects and their prioritization. It is open for any interested citizen. Citizens influence methodology and have decision-making competence, i.e. it encourages strong civil society;

- Representation of organized interests builds on traditional local neo-corporatist arrangements in social and/or economic sectors' discussion of broad political guidelines. It depends on the participation of local associations. The local government is a central actor. Discussions are organized in thematic meetings, but the neighbourhood level is also possible. Discussions deal with general priorities and strategic planning. The position of civil society is weak to medium, as other actors are involved (business organizations and local institutions);

- Community funds at the local and city levels - there is a fund for investments or for projects in the social, environmental and cultural areas. The fund is not created only from the local government budget, but money comes also from companies or other organizations. Priorities are discussed by community groups with some hints of deliberation; businesses are excluded. Community groups are formed by citizens, very often special attention is devoted to specific groups (e.g. ethnic minorities), i.e. civil society has a rather strong position;

- The public/private negotiating table - this model is similar to the previous one since there is also a fund created. At closed meetings involving businesses, local authority, NGOs and citizens, priorities of investment/projects are discussed. Citizens and NGOs have a secondary role and a weak position;

- Consultation on public finances - this model can be seen as a participative version of NPM strategies. Meetings are usually open to all citizens but there is no cycle (often one meeting/year) and no prioritization of investments/projects. Topics of discussion are the evaluation of public services and institutions or budget balancing. Citizens have only consultative influence, their position is rather weak;

- Proximity participation - as in the previous model, participants do not vote or develop priorities for projects. This model usually relies on previous participatory devices, such as neighbourhood funds. Meetings are open to anyone but companies, discussions deal with investments in the neighbourhood and concrete projects without prioritization. Civil society has a weak position, too, as in Consultation on public finances model.

The models of PB in Europe varies but every model enables citizens to participate in passing the budget of the local government either directly or in a mediated way by various representatives (NGOs, community groups). Very important is the 
direct participation, also called participatory democracy or deliberative democracy, which means that the association of non-elected citizens is involved in the decisionmaking process (only in few models). In that sense, the existing models of PB in selected countries and their potential to spread in order to improve the quality of local governance will be analyzed hereafter.

\section{Methods}

The aim of the paper is to provide a comparative analysis of the use and role of $\mathrm{PB}$ in Croatia (HR), Poland (PL) and Slovakia (SVK) and to identify which models of $\mathrm{PB}$ are used in these countries. The countries were chosen due to the fact that these are post-communist countries, where this type of innovation in PA is rather scarce. Therefore the research question is the following: what PB models are used in selected Eastern European countries and how might the application thereof contribute to the quality of local governance?

There has not been much research on PB in any of the Eastern Europe countries, and the analysis of case studies in selected countries should bring useful insights about $\mathrm{PB}$ as a phenomenon that increases citizens' involvement and brings a new way of public-finance redistribution in conditions marked by communism. These countries can be set as an example as they were among the first post-communist countries that adopted PB. In order to compare the case studies of municipalities in selected countries qualitative research methods are applied. Three towns (one of which later split into three local districts) in SVK, almost all municipalities in Poland that have implemented PB as well as towns in Croatia that have implemented (or have stated that they had been implementing) PB were analyzed in the paper.

Regarding the outcomes of $\mathrm{PB}$, we have analyzed to what extent it has been beneficial by comparing the press releases and reports, including citizens' reactions, with official municipality and/or NGO reports about the PB. In order to analyze Poland, secondary data from previous research and studies of other authors (e.g. Sześciło 2012; Kraszewski and Mojkowski 2014) have mostly been used. But for chosen municipalities in PL (as presented later on in Table 2) and for all municipalities in SVK and HR, primary data from municipality websites, press and official reports relating to $\mathrm{PB}$ have been gathered. Personal experiences of the authors in implementing PB have also been used. And in order to analyze selected cases a framework illustrated in the following scheme has been applied: 


\begin{tabular}{|c|c|}
\hline \multicolumn{2}{|c|}{ Analytical framework for case studies } \\
\hline DIMENSION & -STUDIED CRITERIA \\
\hline 1. Origin of $\mathrm{PB}$ & $\begin{array}{l}\text {-PB built on previous participatory devices } \\
\cdot \mathrm{PB} \text { is a break with the past (completely new procedure) }\end{array}$ \\
\hline & \multirow{3}{*}{$\begin{array}{l}\text { - Neighbourhood and/or thematic assemblies } \\
\text { - Closed vs. public meetings } \\
\text { - Regularity (cycle vs. one or two meetings) }\end{array}$} \\
\hline 2. Organization of meetings & \\
\hline & \\
\hline & \multirow{3}{*}{$\begin{array}{l}\text { - Topics of discussion } \\
\text { - Prioritization of topics/projects } \\
\text { - Formal vs. informal discussions } \\
\end{array}$} \\
\hline 3. Type of deliberation & \\
\hline & \\
\hline & \multirow{3}{*}{$\begin{array}{l}\text { - Kind of civil society (does or does not include the } \\
\text { business organizations) } \\
\text { - Type of participating citizens (social sectors, organized } \\
\text { citizens, active citizens, ordinary citizens, all citizens) } \\
\text { - autonomy of civil society (meetings of civil society with } \\
\text { or without administration/councillors) }\end{array}$} \\
\hline 4. Position of civil society & \\
\hline & \\
\hline & \multirow{3}{*}{$\begin{array}{l}\text { - top-down dynamics (municipality initiated PB } \\
\text { procedure) } \\
\text { bottom-up dynamics (citizens or NGOs initiated PB } \\
\text { pocedure) }\end{array}$} \\
\hline 5. Initiators of $\mathrm{PB}$ adaptation & \\
\hline & \\
\hline 6. Amount of budget & - amount of public finance assigned to PB \\
\hline 7. Number of participants & $\begin{array}{l}\text { - active participants (attending meetings and deliberation) } \\
\text { - other participants (on-line voters) }\end{array}$ \\
\hline 8. Number of submitted projects & - submitted projects for the deliberation \\
\hline 9. Number of approved projects & $\begin{array}{l}\text { - approved projects after the deliberation and town } \\
\text { approval }\end{array}$ \\
\hline 10. Outcomes & - results of implemented projects \\
\hline
\end{tabular}

Source: authors, based on Sintomer et al. 2008.

The first five dimensions in the analytical framework allow us to identify what model of PB has been in use in selected cases based on models defined by Sintomer et al. (2008). Therefore these dimensions are not discussed later on individually, but they serve to identify the used models which are compared in the findings. The points 6-10 make a comparison possible of PB in Croatia, Slovakia and Poland, within and between countries.

\section{Participatory budgeting in Croatia}

The analysis conducted in Croatia showed that PB practices in Croatian local units were not well developed. Several towns have some experience with engaging citizens in the preparation of the local budget, but in most of the cases it is just a kind of "soft consultation" process without real engagement of citizens in the decision-making process on concrete financial sums. Therefore, the types of engagement vary from a 
mere invitation to submit a proposal to the devolution of decision-making through a prioritization of sub-municipal projects.

The town of Pazin is often indicated as a positive example because of its most holistic approach to the involvement of citizens in the prepration of the local budget and the promotion of the project in media at the local and national levels. According to the census determined in 2011, Pazin has a population of 8,638 . The approved total local budget for the year 2015 amounts to 75,203,945.00 kn (app. 9,900,000,00 $€)$. On the proposal of the civil-society organization GONG, and in cooperation with several other civil-society organizations, Pazin launched a pilot project of $\mathrm{PB}$ in February 2014. The aim of the project was to involve the citizens and the wider public in the planning and creation of the budget for the year 2015. The project started with the preparation of materials and familiarizing local civil servants with the project. A public presentation took place in June, when the mayor invited citizens to submit their proposals on utility services in their sub-municipal entity by e-mail or surface mail. Since some sub-municipal entities did not submit any proposals during the first round (until the end of July), the deadline for submission was prolonged until the end of August. In addition, the project was promoted through leaflets, radio shows, a special web-site, personal contacts and information within sub-municipal entities. Approximately one hundred proposals were analyzed, and financial assessment was done by the team of local civil servants. The feedback on proposals was given in public hearings which were held in all 12 sub-municipal entities in September. The citizens were invited to propose large utility actions and to vote for priority small utility projects. In October, four public discussions within the sectors of social security and health, economics and tourism, culture and tourism, education and sport, and one discussion within the sport sector on special citizen proposal were carried out. The aim was to collect the opinions of local stakeholders and to indicate the priorities for financing within each of the sectors analyzed. Finally, all citizens' proposals regarding small utility actions (19) and part of other proposals were accepted by the local council. Proposals on regular utility actions were immediately included in local activities. Approximately $6.8 \%$ of population have participated in the $\mathrm{PB}$ and decided on $0.4 \%$ of the total local budget (app. $40,000.00 €$ ). The project was finalized with a visualization of the budget in a form suitable for citizens and a video presentation of the PB process. In order to control the implementation of the budget and especially the realization of small utility actions proposed by the citizens, a citizens' board is planned to be formed.

Crikvenica is probably the town with the oldest tradition in consultation on local-budget practices in Croatia. It has been organizing public hearings and issuing the leaflet on the local budget since 2002. Although the proactive approach of the civil servants in local administration is complimentary, there is plenty of space for improvement. It might be better to replace one public hearing of general character conducted at the local level with several discussions at lower levels of government. In addition, the determination of the amount the citizens can decide on, the subject 
of discussion and the control of implementation would make the existing process more "participatory".

The town of Rijeka has been implementing a rather extraordinary form of consultation on the local budget, namely an educating online game which provides the citizens with the opportunity to manage public income and expenses. They can also propose projects not included in the actual budget in the amount of $60,000,000.00 \mathrm{kn} / \mathrm{app} .7,900,000.00 €$ (app. $7.5 \%$ of the total budget, which amounts to app. $105,000,000.00 €$ ) and provide the resources for their realization by lowering actual budget items or increasing taxes. There are 7,000 visits to this web site per year and 1,500 participants finish the game each year. The game is of an educative, informative and consultative nature since it includes explanations of key words, items and amounts of the actual budget, links to legal resources and relevant documents, and the possibility for the citizens to choose among offered projects. In addition, the proposals of the projects and savings are delivered to and collected by local administration. Statistical information is hence forwarded to the mayor and city managers. Although interesting and educative, the online game might leave the impression that city government does not regard citizens as adequate partners in the development of the local budget. Accordingly, it should be broadened with additional forms of citizen participation in the budgeting process. Since Rijeka has already developed a system of e-consultation, the next step would be also to include consultations on the local budget.

The town of Pula with a population of 57,460 inhabitants has been engaging citizens in the preparation of the local budget since 2012. However, the process is limited to mere consultation through e-consultations, e-mails and public hearings at the sub-municipal level. Only 25 days were provided for the consultation process. Although the intention of public hearings is to provide the interested public with the opportunity to submit proposals on priority local projects, dialogues with local civil servants were often related to informing on the budgeting process and implementation of projects in progress. The process is not elaborated enough: neither the proportion of the budget nor the content of discussion is defined. Since the local administration and the local council are not obliged by proposals, the control over the implementation of specific citizens' proposals is not provided. However, on the initiative of the NGO Zelena Istra (Green Istria) and within the project "Participatory budgeting: citizens monitor local budget", a working group for the citizen supervision over the spending of local public finances was established in 2015. For 2015, the council approved the total budget of 345,326,466.00 kn (app. 45,440,000.00€). In spite of the fact that Pula belongs to the group of large cities in Croatia, only 250 inhabitants participated in public hearings on the local budget and 120 proposals were submitted via e-mail in 2012.

As of the beginning of 2015, Pula participates in the project "Participatory budgeting: citizens monitor local budget” together with Mali Lošinj and Karlovac. 
The project is being implemented in cooperation with several local civil-society organizations as well as one international one. So far, web portals with relevant information on the local budget and the possibility for citizens to submit their proposals have been created for each town. The idea is to collect proposals on local projects and to choose those that are supported by the majority of ballots. Afterwards, NGOs submit selected proposals to local government. In 2015, local government in Mali Lošinj decided to devote $180,000.00 \mathrm{kn}$ (app. 24,000.00 €) to the projects proposed by citizens, which amounts to ca. $0.23 \%$ of the total local budget from 2015 . Although some steps in the process of citizen participation in the preparation of the local budget have been taken, citizens are still rather limited in their efforts to make crucial changes, since the final decision on the acceptance and financing of the proposals is made by the local government. However, higher participation of citizens in this process and their pressure on local government might change the existing low level of direct citizen impact on decisions issued by local political bodies.

Participation of citizens in the preparation of local budgets in Labin and Slavonski Brod is at the very beginning. Whereas the town of Labin has given its citizens an opportunity to give their proposals on projects during the public hearings in sub-municipal entities, practices in Slavonski Brod are limited to consultations through e-mail and e-consultations. Although the possibility of indirect participation in the preparation of the budget for 2015 was provided in Labin, there were no suggestions, complaints or opinions expressed by the representatives of the interested public. It seems that a higher level of informing and even marketing is required for citizens in order to encourage them to participate in this process.

Since most initiatives of citizen participation in the preparation of local budget in Croatia are not developed and elaborated yet, it is hard to speak about PB and even harder to speak about specific model(s) of PB in Croatian local units. The prevailing part of analyzed local units is primarily oriented to make the local budget transparent and understandable for the citizens, and thus only includes information as a one-way communication between government and citizens. However, some of them have been implementing non-obligatory consultation practices (mostly econsultations) which may be considered a kind of PB model, which Sintomer et al. $(2008,172-173)$ call "Consultation on public finances". Half the towns have been organizing public hearings and discussions about local needs and required projects at the sub-municipal level and in cooperation with local administration, which are the characteristics of "Proximity participation". However, the model implemented in Pazin is the most elaborated one. Since it includes the direct participation of individual citizens, who decide on concrete investments and projects with a large share of proposal acceptance, this model is closest to the original PB model, i.e. "Porto Alegre adapted for Europe" (Sintomer et al. 2008, 170). As the most developed local unit regarding PB practices in Croatia, the town of Pazin, i.e. its PB model, is represented in Table 1. Other forms of engaging citizens in the preparation of the local budget should not be characterized as developed $\mathrm{PB}$ practices (yet). 


\section{Table 1}

Participatory budgeting in Croatia - the town of Pazin

\begin{tabular}{|c|c|c|}
\hline & \multicolumn{2}{|c|}{ Pazin } \\
\hline Population & \multicolumn{2}{|c|}{8,638} \\
\hline Year & \multicolumn{2}{|c|}{2015} \\
\hline Origin of PB & \multicolumn{2}{|c|}{ Completely new procedure } \\
\hline $\begin{array}{l}\text { Organization } \\
\text { of the } \\
\text { meetings }\end{array}$ & $\begin{array}{l}\text { Public meetings organized by lo- } \\
\text { cal authorities in co-operation with } \\
\text { NGOs and held in all } 12 \text { sub-munic- } \\
\text { ipal entities } \\
\text { On-line moderated forum }\end{array}$ & $\begin{array}{l}\text { Four public discussions within spe- } \\
\text { cific sectors (social security and } \\
\text { health, economics and tourism, } \\
\text { culture and tourism, education and } \\
\text { sport), and one discussion within } \\
\text { the sport sector on special citizens } \\
\text { proposal organized by local authori- } \\
\text { ties in co-operation with NGOs } \\
\text { On-line moderated forum }\end{array}$ \\
\hline $\begin{array}{l}\text { Type of } \\
\text { deliberation }\end{array}$ & $\begin{array}{l}\text { Proposals and open discussion fo- } \\
\text { rums on large utility actions and } \\
\text { deciding on priority small utility } \\
\text { projects }\end{array}$ & $\begin{array}{l}\text { Proposals and open discussion fo- } \\
\text { rums }\end{array}$ \\
\hline \multirow{2}{*}{$\begin{array}{l}\text { Position of } \\
\text { civil society }\end{array}$} & $\begin{array}{l}\text { All citizens can take part in PB pro- } \\
\text { cedure, but deciding is limited to } \\
\text { small utility actions and discussion } \\
\text { related to large utility projects }\end{array}$ & $\begin{array}{l}\text { All citizens can take part in discus- } \\
\text { sions limited to five thematic areas }\end{array}$ \\
\hline & \multicolumn{2}{|c|}{$\begin{array}{l}\text { Ordinary citizens were involved neither in establishing methodology for } \\
\mathrm{PB} \text {, nor in verifying the submitted projects or monitoring the implementa- } \\
\text { tion of projects selected in voting. }\end{array}$} \\
\hline $\begin{array}{l}\text { Initiators } \\
\text { of PB } \\
\text { adaptation }\end{array}$ & \multicolumn{2}{|c|}{$\begin{array}{l}\text { The mixture of top-down and bottom-up dynamics (local authorities in } \\
\text { cooperation with NGOs initiated PB procedure) }\end{array}$} \\
\hline $\begin{array}{l}\text { Participatory } \\
\text { budget in } €\end{array}$ & \multicolumn{2}{|c|}{$40,000 €(0.4 \%$ of total town budget $)$} \\
\hline $\begin{array}{l}\text { Number of } \\
\text { participants }\end{array}$ & \multicolumn{2}{|c|}{$488(6,8 \%$ of those eligible to vote) } \\
\hline $\begin{array}{l}\text { Number of } \\
\text { projects } \\
\text { (submitted } \\
\text { projects) }\end{array}$ & \multicolumn{2}{|c|}{$>100$ projects on small utility actions } \\
\hline $\begin{array}{l}\text { Number of } \\
\text { approved } \\
\text { projects }\end{array}$ & \multicolumn{2}{|c|}{19} \\
\hline Outcomes & \multicolumn{2}{|c|}{$\begin{array}{l}\text { Reconstruction of bus shelters, road construction and renovation, con- } \\
\text { struction of school sport fields and external sports gym, provision of sew- } \\
\text { age tank, sidewalks and parking facilities, street-lights }\end{array}$} \\
\hline PB Model & \multicolumn{2}{|c|}{ Porto Alegre adapted for Europe } \\
\hline
\end{tabular}

Source: authors 


\section{Participatory budgeting in Poland}

For the first time in Polish reality a form of $\mathrm{PB}$ appeared in Plock, where in 2003-2005 Town Hall, the company PKN Orlen and the UN created the so-called "grant fund", where local NGOs applied for funding for their projects (Grant Fund for Plock). In 2011 PB appeared in Sopot as a specific "civic budget". Since then, the Sopot experiment has inspired many local governments in Poland. By the end of 2013, at least 72 towns and cities in Poland had decided to implement PB (in the form of the city council's resolution or the mayor's directive). Citizens have already made their decisions on expenditure in 52 of them.

Table 2 shows the cases of three towns regarding PB practices in Poland. The selection of these towns was guided by the criterion of similar population sizes so that a comparison to the Slovak units could be made.

Sopot has the longest experience in the implementation of PB in Poland. The initiator was Sopocka Inicjatywa Rozwojowa (NGO), implementing a social campaign, "Democracy is not just elections". New members of the Town Council elected in November 2010 were in favour of this initiative, and it resulted in the adoption of PB in May 2011 by establishing the Citizens Budget Committee for the Sopot Town Council. Finally, in August 2011 the committee established the principle of the PB process, and residents were invited to submit proposals for projects. Residents could propose projects without any topic or financial limitation. Submitted projects were subject to verification in terms of feasibility, compatibility with existing plans and formal and legal regulations. Meetings with residents in districts were organized by the Town Council. Voting for projects took 6 days. Residents voted using paper cards distributed in designated places in the town or at meetings or electronically. They could vote on their district projects but also on projects in the whole town. So far there were already 4 PB cycles in Sopot. During these cycles not much changed in the procedure of $\mathrm{PB}$, just some formal and legal criteria were added, and time for voting was prolonged. Inactive citizens do not participate in setting policies of $\mathrm{PB}$, in verifying the submitted projects or in monitoring the implementation of the tasks involved in $\mathrm{PB}$.

In Gdansk, the first discussions on more involvement of residents in decisions concerning the city appeared at the same time as in Sopot, in 2011. However, the lack of interest on the part of the city extended to the way of implementation of PB. The influence of lobbying on the part of the district councils resulted in formulating a statute of PB in Gdansk in August 2013, approved by the City Council. In order to develop a procedure for PB in October 2013, the mayor of Gdansk appointed the Consultation Committee with 21 members for the pilot project "Citizens Budget 2014 in Gdansk". The Committee consists of representatives of the City, the City Council and local NGOs. As a result, 2.1 MM $€$ was allocated for the implementation of 28 projects selected by the residents in the city budget for 2014 . For the 


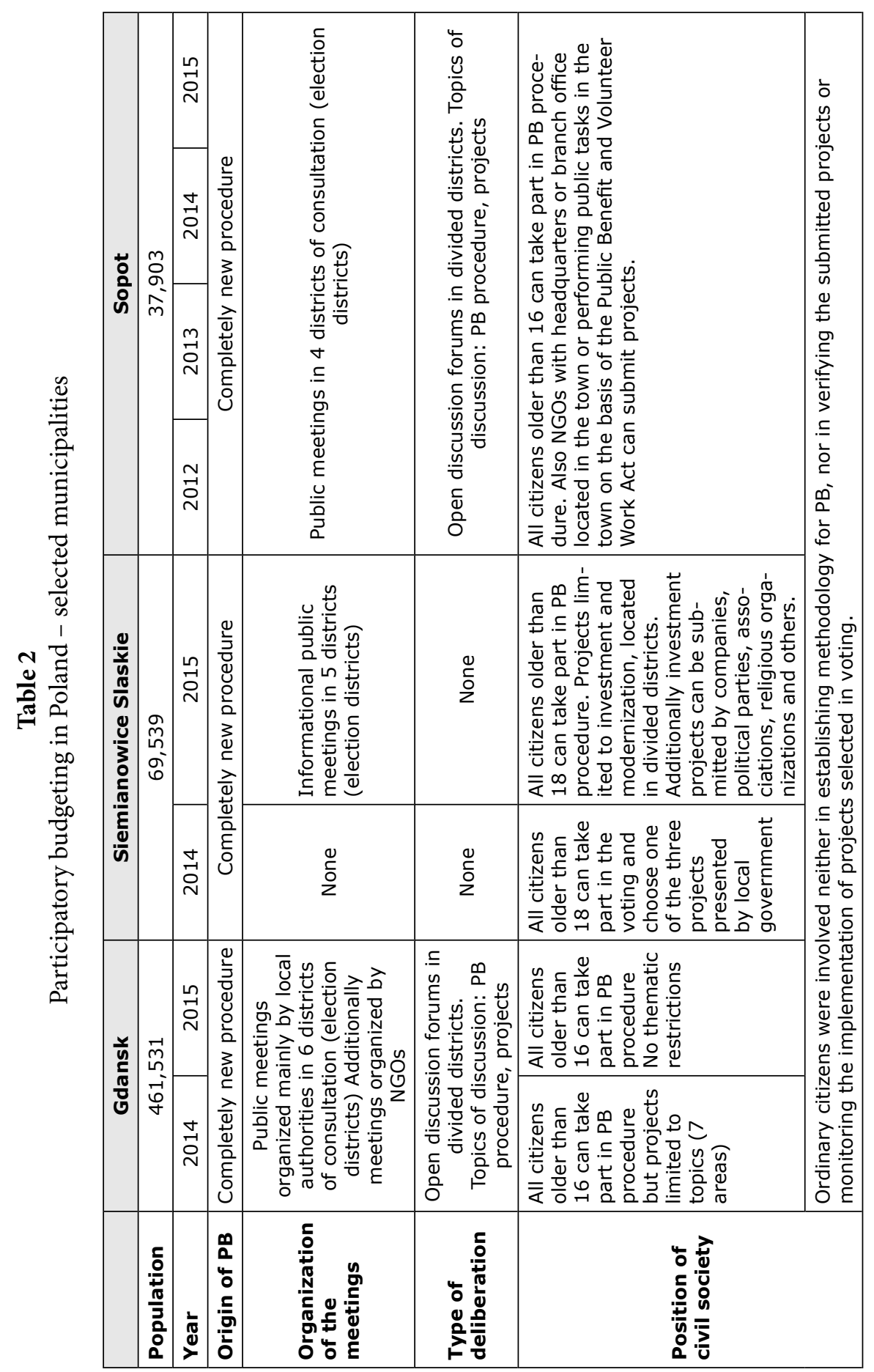




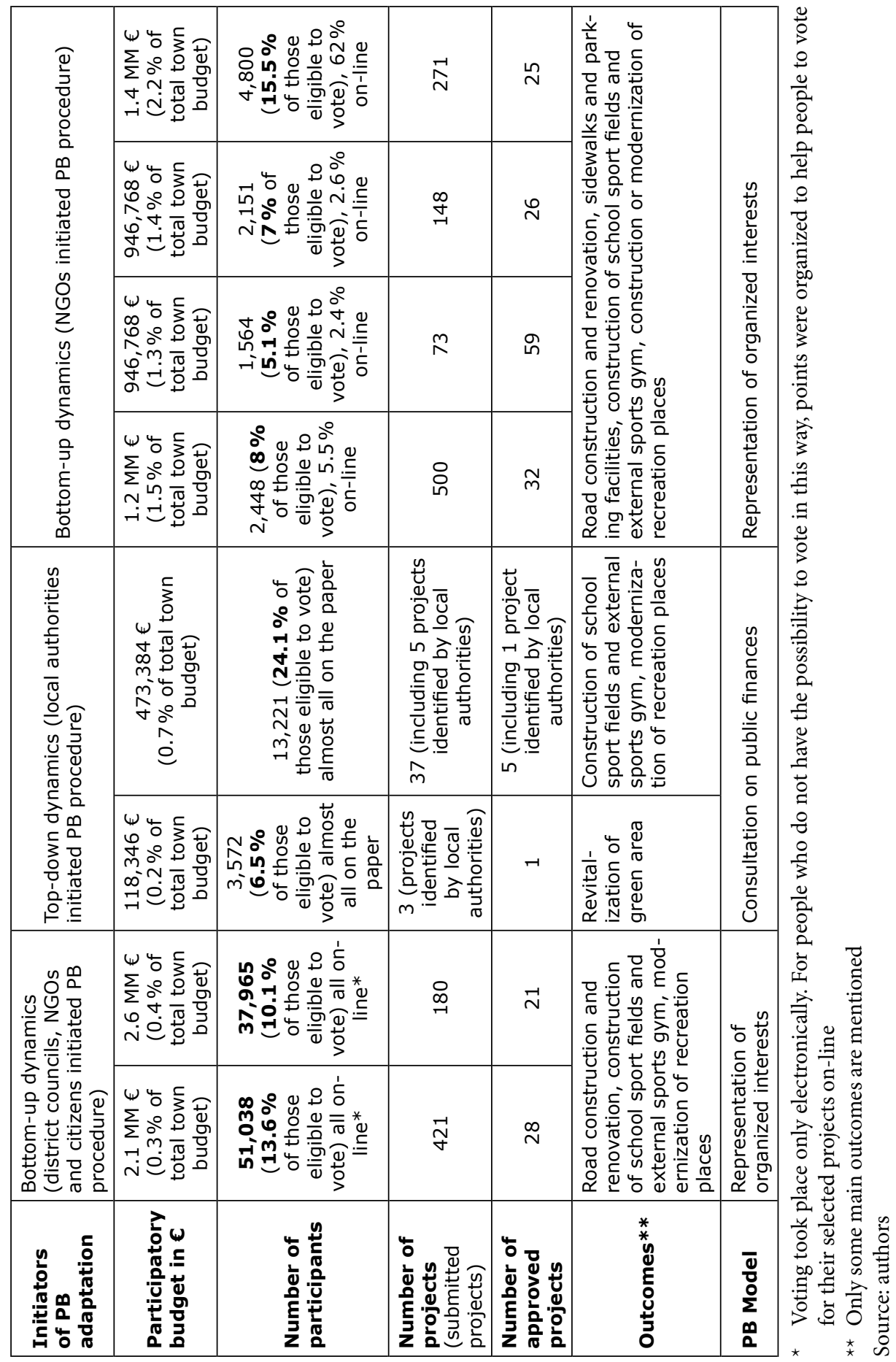


purpose of PB procedure the city was equally divided into 6 consultation districts according to the total amount allocated for PB. In the first year of the PB, residents submitted drafts of seven thematic areas but rather broadly formulated: recreational areas and their infrastructure, tourist shelter and information, changes in the organization of traffic, safety in the streets, road repair and renovation of urban places and public facilities. The proposal of projects was preceded by an information campaign also involving the meetings organized by the City Council, where residents learnt about the idea of $\mathrm{PB}$, and also consultations on proposals for civic projects were held in these meetings. A parallel information campaign was organized by local NGOs. In the second year PB slightly improved its procedure, resources allocated for PB projects increased and thematic limitations of proposed projects were abandoned. In both years, the vote took place only electronically. For residents who cannot vote, meeting points were organized where they could cast their ballots with the help of designated people.

Among the towns shown in Table 2, Siemianowice Slaskie has the shortest experience in the implementation of $\mathrm{PB}$, and they chose different $\mathrm{PB}$ model than most of the Polish municipalities. The process started in 2013 and was named "Citizens Green Budget" by the town authorities. The town council invited adult residents to vote in the period from November to December 2013 for one of three projects for the revitalization of green areas in Siemianowice Slaskie. For the implementation of winning project that received the most votes, the town of Siemianowice Slaskie allocated 118,346 €. In 2014 there was no significant progress in the procedure: the role of the local community remained still limited, information meetings were organized for the residents as information points in the district, projects were proposed in the first place by the town. What has changed was the introduction of so-called additional proposals, limited to projects with an investment and modernization that can present individuals, companies, political parties, associations, religious organizations and others. These additional proposals must include the costs of execution and be supported by at least 100 residents (proved by signatures). The criteria for the verification of submitted projects included the principle of legality, efficiency, economy and effectiveness. Verification was carried out by a committee established by the mayor. Residents could vote only for one project. In 2014, four projects proposed by residents and one town project were approved.

Summing up the above discussion, most of the PB solutions in PL are similar to the "Porto Alegre adapted for Europe" model as described in the literature (Sintomer et al. 2008). It is mostly a break with the traditional methods of financing public services; procedure is open to all citizens and includes deliberation. But citizens have a rather weak position; they do not influence the methodology, which makes it more similar to the "Representation of organized interests" model. Every local government unit introduces its own PB rules, often being guided by examples of other towns and on many occasions not having social consultation and not working on the principles of $\mathrm{PB}$ together with citizens. 


\section{Participatory budgeting in Slovakia}

In Slovakia there are three municipalities that have implemented participatory budgeting so far. The first municipality was the city of Bratislava in 2011, followed in 2013 by the town of Ružomberok, and the latest town with PB is Banská Bystrica, in its first year in 2014. In all three towns, the process of PB was started by an initiative of a local NGO and the work of volunteers. There are only three cases of $\mathrm{PB}$ in Slovakia so far, so it allows us to provide a deeper analysis, but for the sake of the presentation we will state only the most important facts for every town. The summary of PB in Slovakia is in Table 3.

The case of Bratislava was specific because in the first year (2011) the money for PB $(15,000 €)$ was gained from sponsors, not from the public budget. The process of implementing PB was started in a bottom-up way, where active citizens and the NGO Utopia raised the money, established co-operation with the city council and involved other citizens. Approximately 200 citizens participated in 5 thematic communities (1. Youth, 2. Seniors, 3. Culture, 4. Green town, 5. Cycle - transport), and for each community up to 3 projects were selected. The winning projects were approved in a deliberation process, and the city council formally decided on spending the money for the proposed projects. In the next year the Bratislava City Council allocated $29,975 €$ from its budget and for 2013 it was $46,000 €$. The priorities for 2013 chosen by citizens were in these areas: 1 . Youth, 2 . Seniors, 3. Culture, 4 . Green town, 5. Transport in town, 6. Open data and 7. Community centre of generations. In 2014 topics for projects were narrowed down to 4 areas: 1. Youth, 2. Seniors, 3. Green town, 4. Open data.

Yet, the problem is that the city saw to it that the amount for $\mathrm{PB}$ would be 1 per cent of the total costs, which should be around $2 \mathrm{MM} €$. This is highly demotivating for volunteers who devoted their free time and work to the projects but lack the funding. The city of Bratislava is challenged by other problems; currently the most serious ones are publicity of $\mathrm{PB}$ (the city does not use its channels to inform the citizens about $\mathrm{PB}$, everything is in the hands of the initiating NGO and volunteers, which decreases the number of participating citizens); problems with tranches (delayed tranches for some projects, non-transparent process of drawing money) and the quality of deliberation (NGO strongly prefers public meetings, whereas the city wants on-line voting, where the deliberation is endangered; therefore the on-line voting has only 10 per cent weight). These challenges have led to the division of $\mathrm{PB}$ in Bratislava to local districts, in 2013 it was Bratislava (BA) and Petržalka (Pet) and in 2014 Bratislava, Petržalka and Nové mesto (NM).

Petržalka has implemented a different model of $\mathrm{PB}$ - projects are presented by the municipality in three categories, and citizens can only vote which one will be realized in each category. These categories are: 1. New greenery, 2. Stairs (public 
spaces) and 3. Sport (renovation of sport areal, gyms, playgrounds). This is the socalled model of Consultation on public finances.

Nové mesto adapted the "Porto Alegre adapted for Europe" model, with public deliberation and a voting system where votes cast at the deliberation have $50 \%$ weight, on-line voting has $20 \%$ weight and voting at 11 designated points has $30 \%$ weight. Priorities for projects were chosen by citizens at the first open discussion forum as follows: 1 . Youth, 2. Seniors, 3. Green town 4. Public spaces and urbanism.

In Ružomberok the PB process started in 2013 based on the initiative of the NGO Tvorivý Rozvoj (Creative Development) in co-operation with the experienced NGO Utopia, which helped to implement and establish PB in Bratislava. In the first year, two thematic communities (Green town and Youth) were created, where citizens met and discussed the ideas on the improvement of municipal services and environment. Out of 7 submitted projects, 6 were approved in the election, which consists of public deliberation and on-line voting. As the initiators of $\mathrm{PB}$ in Ružomberok aim to increase citizens' participation in public life, the votes given to the projects after the deliberation process have a weight of 90 per cent, and online voting makes up 10 per cent. This step should motivate citizens to come to the public forum for the deliberation process and increase active citizenship. Another step to ensure this increase in civic participation is that projects can be submitted only by citizens who actively meet during the year at the thematic assemblies. As for voting, anybody with permanent residence and over the age of 18 can vote. Projects are then ordered by the number of votes, and those supported are those which gain most of the votes down to when the amount for PB is spent. These projects are officially approved by the town council. So far, neither the initiators, town deputies and public servants, nor the citizens have encountered any serious obstacles or problems. The challenge is to increase the number of projects (to do so, another thematic community was created - Urbanism) and to increase the amount of money allocated for PB in Ružomberok.

Banská Bystrica (BB) used PB for the first time in 2014. The initiators were the NGO Via Altera in cooperation with NGO Utopia and one deputy from local government. This fact is noteworthy, as there were local elections in Slovakia in November 2014 and the step of supporting PB was aimed at getting some extra votes from those activists who appreciate that they can decide on public spending. Despite the deputy support, which enabled a smooth passing of PB in the town council, there were several problems in the pilot year.

First of all, the money allocated for PB was taken from so-called civic councils. These councils were assigned $1.5 €$ per citizen living in the district of each council from collected local taxes (there are 11 civic councils for 11 districts in BB). In 2014 it was only $1.25 €$ per citizen and the rest of the amount $\left(0.25 €^{\star} 77,820\right.$ citizens) was assigned to PB. This minor drop in funding for civic councils has evoked a big wave of disagreement. The members of civic councils complained that they were elected 
for deciding how to spend public money in their districts, and they wanted to disrupt the process of $\mathrm{PB}$. Their protests stopped when they found out that they could also apply with the projects, this time as regular citizens, not as elected bodies. Indeed, 2 out of 4 approved projects were submitted by citizens from these civic councils. The second problem is the low level of interest of public servants to cooperate. The deputies are in favour of $\mathrm{PB}$, but the public servants see it as another burden when they have to deal with citizens working on approved projects and monitor their financial reports. But despite the problems, PB will continue in 2015 with the amount of $19,343 €$.

The PB process is very similar to that in Ružomberok but with three differences. All citizens over the age of 15 with permanent residence in $\mathrm{BB}$ are eligible to vote, which empowers also young people to decide and increases their participation. Secondly, not only citizens who actively participate in thematic assemblies can submit a project; project submission is open to all citizens over the age of 18 with permanent residence, or if a younger citizen wants to submit their project this must occur with the approval of their lawful guardian (usually a parent). The third difference is in the voting. In BB there is no on-line voting. Citizens can vote either at the public forum after the deliberation process, where they can hear the presented projects and ask questions, or in the town hall by casting their votes after checking their residency at the clients' zone. In the town hall it is possible to vote for one project only, and that vote has the value of 1 point. At the public forum those citizens who participated in the deliberation process can vote for three projects, and based on their priorities they can assign 5 points to the project they like the most, 3 points to the second and 1 point to the third project. The intention is not only to involve the public in the creation of the public budget and to raise their interest in and understanding of the town financial mechanism but also to choose such investments and projects that really matter. In the first year, residents chose six areas: 1 . Culture, 2 . Community life and active citizenship, 3. Youth, 4. Greenery in town, 5. Sport and 6. Health.

Participatory budgeting in Bratislava, Nové mesto, Ružomberok and Banská Bystrica was implemented with the help of Utopia (NGO), which is active in various projects that increase citizenship participation. This idea is also to spread PB in Slovakia, where they advise municipalities to use such models of $\mathrm{PB}$ where active citizenship and direct democracy is strengthened. More information on PB in each analyzed town is in Table 3, which follows the analytical framework. Moreover, following these positive examples, other municipalities in Slovakia are preparing to start PB from 2015 on, e.g. the towns of Šala, Brezno and Zvolen.

As can be seen in Table 3 the thematic communities are from the fields of public services, i.e. all projects involve citizens as co-creators of public services. Citizens create the projects based on their needs and priorities, and in the deliberation process they choose the winning projects to be implemented. In this process they are also educated about public finance and its allocation. These steps increase account- 


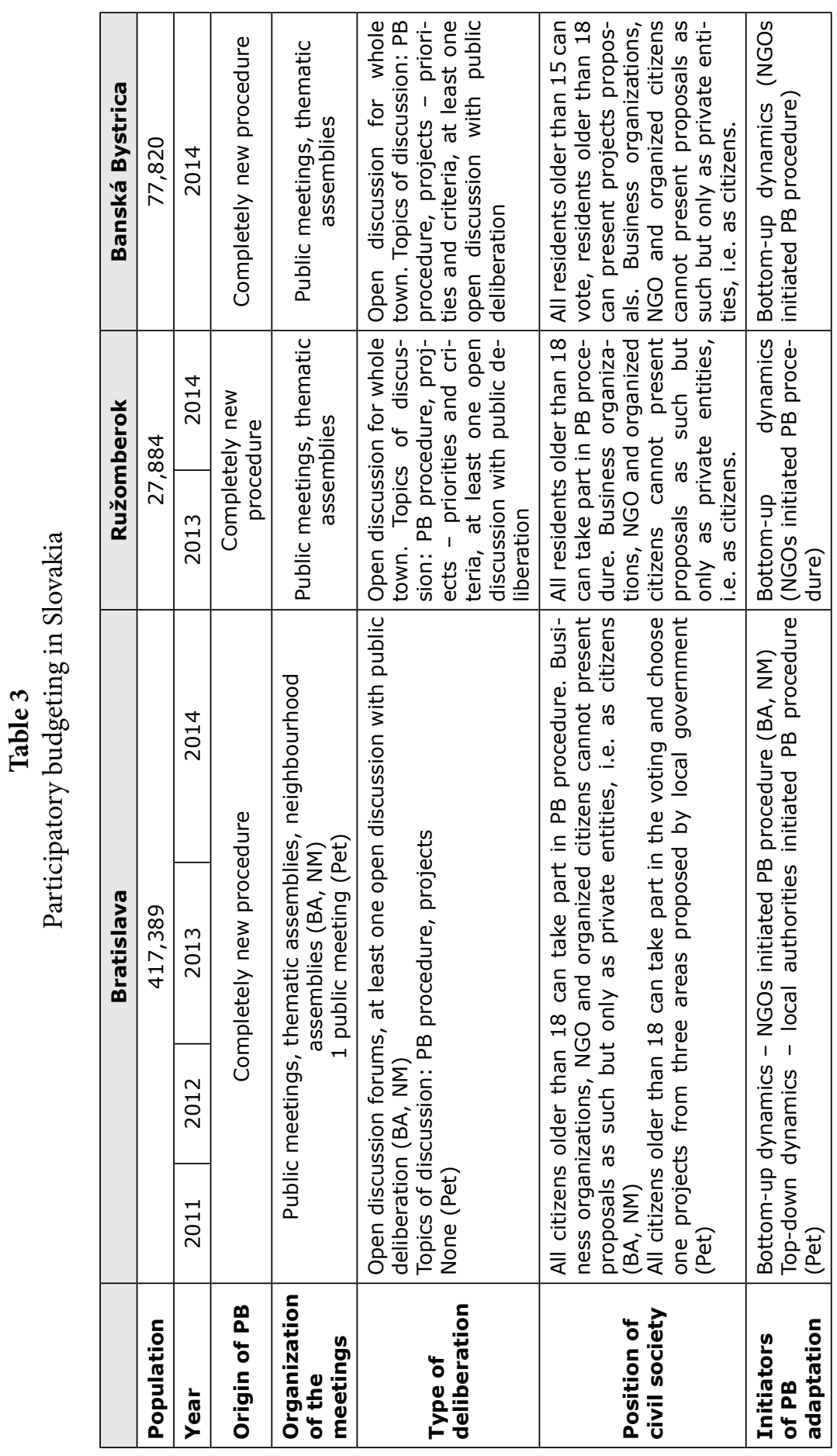




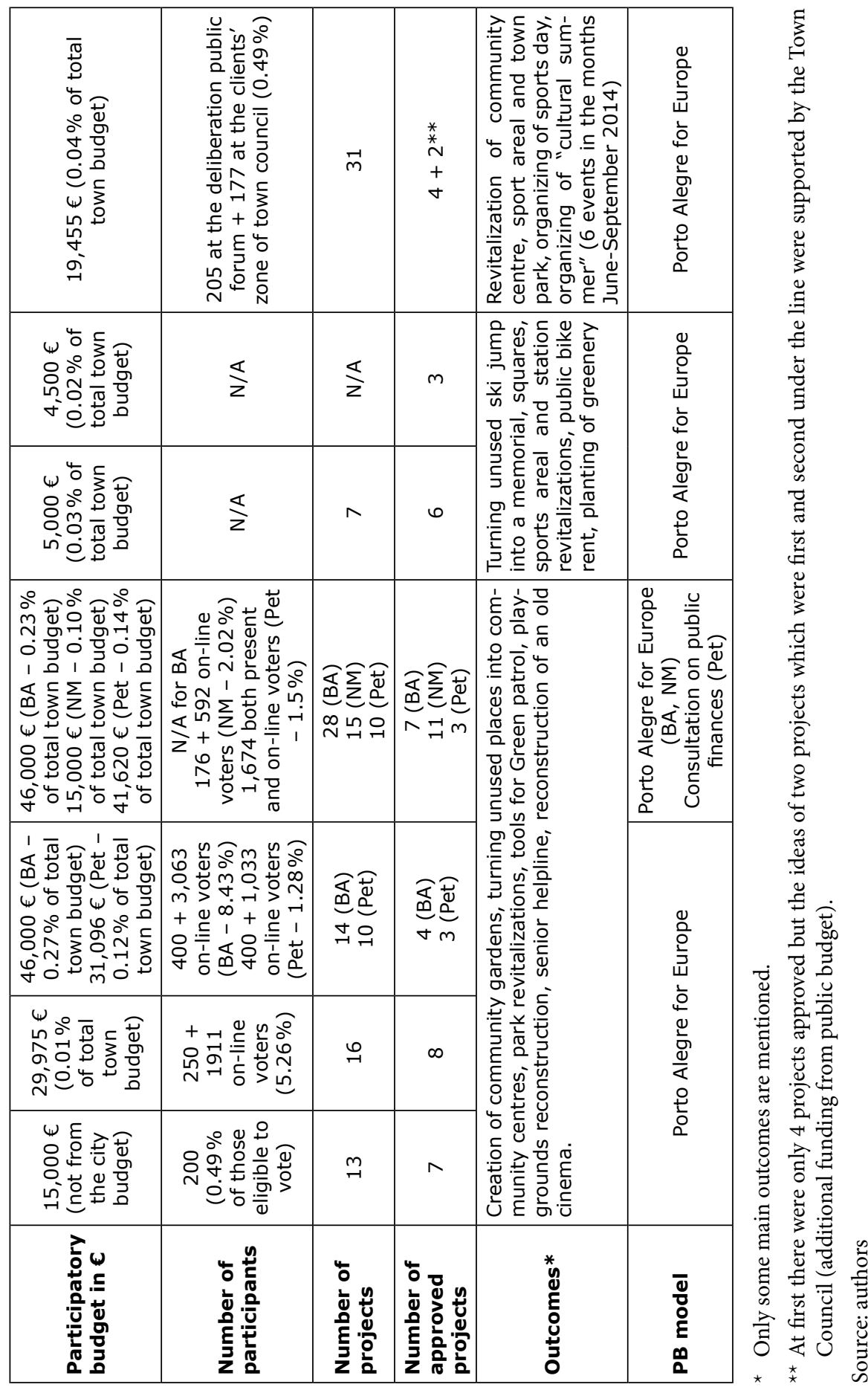


ability, transparency, openness and education, as well as direct democracy, which are all parts of the good-governance concept.

To sum it up, we can state that most towns with PB in Slovakia use the model called "Porto Alegre adapted for Europe" with really strong civil society where citizens can also consult and influence the methodology and statute of PB. Only Petržalka has chosen a "Consultation on public finances" model, as defined above by Sintomer et al. (2008).

\section{Findings and discussion}

Based on the analytical framework (scheme 1, dimensions 1-5) the following models of PB are identified in HR, PL and SVK: mostly "Porto Alegre adapted for Europe" and "Representation of organized interests", and occasionally "Proximity participation" and "Consultation on public finances". The last model does not contribute that much to the participation of citizens (no meetings in thematic communities or neighbourhoods, no implementation of the projects), and it has a rather low deliberative quality. On the other hand it brings local governments closer to the citizens by providing an opportunity to advise on public spending and orientation of the services. It also uses innovative techniques for the association of ordinary citizens - not only the active citizens are present, but meeting once a year is also acceptable for ordinary citizens who do not want to be too involved in public-domain participation.

Following the analytical framework (scheme 1, dimensions 6-10 on number of participants, number of projects and amount for $\mathrm{PB}$ ) several interesting findings can be indicated.

The size of municipalities that implemented $\mathrm{PB}$ varies from 5,000 to $1.7 \mathrm{MM}$. inhabitants in Poland and from 27,000 to 420,000 inhabitants in Slovakia, and it can be stated that PB is very highly represented among mid-size and large towns and cities (Kraszewski and Mojkowski 2014, Kłebowski 2014). PB has been introduced in ca. $80 \%$ of cities over 300,000 inhabitants, over $60 \%$ of cities over 100,000 inhabitants, but also ca. $0.2 \%$ of local governments below 5,000 inhabitants and $0.3 \%$ of local governments below 10,000 inhabitants. But taking into account citizen involvement in comparison to the size of the municipality, the results vary. In SVK it is less than 1 per cent, e.g. for BB there were 382 voting participants, which is only half a per cent of the total town population. The question arises whether these participants were only those who submitted project proposals (including their relatives and friends), and they came to vote for themselves. Then the idea of citizen involvement is not highly supported by PB. On the other hand, in BB there was no on-line voting. Compared to some Polish towns where on-line voting was enabled and the turnout was $26.5 \%$, almost three quarters of which were on-line votes, we can state that the use of information technologies (IT) may contribute to the imple- 
mentation of $\mathrm{PB}$ as an innovation in the public-services provision and the direct participation of citizens. In Croatia, the situation is rather different. There are very few towns implementing some kind of $\mathrm{PB}$ practices. Their population varies from 8,000 (which is below the number of inhabitants legally required for the establishment of a town) to more than 128,000 inhabitants. ${ }^{4}$ However, in most of the towns participation of citizens is very low. In the case of Labin none of them participated in public hearings on the local budget for 2015. On the other hand, almost $7 \%$ of the citizens in Pazin were involved in the preparation of the local budget in 2014. Since the possibility of on-line voting is not provided yet, it is hard to draw any conclusions on the linkage between the rate of participation and the means of voting. Nevertheless, it seems that the usage of IT in the preparation of local budgets is recognized by local administrations and citizens since there are on-line forums for discussion on this topic, and citizens are invited to submit their proposals through the e-consultation process, which they use to a significant extent (at least in the towns of Pula and Pazin).

It is quite surprising that based on the comparable size of the municipalities, e.g. Sopot in PL $(37,903)$ and Ružomberok in SVK $(27,884)$, the number of submitted projects varies a lot: in Ružomberok there were only 7 proposals (and 6 approved projects), in Sopot there were 73 proposals (and 59 approved projects) in 2013 (both towns have the same model of PB implemented). On the other hand regarding the amount of PB, Sopot assigned $1.3 \%$ of the total town budget, Ružomberok only $0.03 \%$, i.e. citizens probably were not motivated enough to submit their projects in Ružomberok due to the low amount of the budget. However, the citizens of Pazin in HR could decide on the usage of a small amount of the local budget $(0.4 \%$ of total town budget), but more than a hundred proposals on small utility projects were submitted in 2014 (out of which 19 were accepted).

In terms of the amount allocated for PB, Polish cases are again better with higher relative amounts (from $0.2 \%$ up to $2.2 \%$ ) whereas in Slovakia the PB amount has between a $0.01 \%$ and a $0.27 \%$ share of the local budget. While the budgeting impact seems little, to put it generously even $0.01 \%$ of the total local budget has a significant symbolic impact, and that process has brought more minority and lowincome people, but also young people, who usually are not interested in politics, into the democratic process and decision-making. In most of the towns in Croatia, the amount of the budget that citizens can make proposals on is not defined. It is probably due to the fact that they do not have real deciding authorities. An exception is Pazin, where citizens can decide how to spend $0.4 \%$ of the total local budget, and Mali Lošinj, where local government determined ca. $0.23 \%$ of the total local budget as the fund for the projects proposed directly by citizens.

4 Pursuant to Croatian Law on Local and Regional Self-Government, each town with more than 35,000 inhabitants belongs to the category of large towns. 
The amount assigned for PB is rather low in all countries, yet in Poland we can see it has spread into many municipalities; meanwhile in Croatia there are 8 municipalities using PB (but only under a wide understanding of PB) and in Slovakia only 3 municipalities. The participation of citizens in public affairs in PL and SVK is not something common, since a strong centralized state and a dominance of the political power of the Communist Party over all subsystems of public administration did not support the involvement of citizens in policymaking. After the end of the communist era in 1989 the third sector started its boom, and it was the opportunity for citizens to group and to express their opinions on public affairs. It was earning the public trust thanks to a different way of management and financing (Vaceková 2013; Michalski et al. 2011). However, the situation in Croatia was somewhat different due to the primacy of local political communities and wider possibilities of citizen participation during the socialist period (Koprić et al. 2014, 254).

In all countries the outcomes of projects are within the field of public services, and they are very similar, mostly the projects are in the sectors of environment, children and youth, seniors, healthcare and sport. Also, in all countries the process has been implemented only recently, and the idea is mostly to increase citizens' participation in deciding on public services provision and to strengthen direct democracy in the process of public deliberation. In the process of the "Porto Alegre adapted for Europe" PB model citizens are also invited to take responsibility for the realization of the winning projects. They are involved in all phases of the preparation of the local budget. Thus in almost all analyzed Slovak and Polish cases the citizens' participation is very active, except for the case of Petržalka (SVK) and Siemianowice Śląskie (PL), where citizens do not have to implement the project but only vote for projects that the municipality district suggests. Public agencies deliver the projects, and the citizens' role is only to decide and later on monitor (but only in the case of SVK, in PL citizens do not monitor in any models). In Croatia, the active part of citizens in implementing or monitoring the selected projects has not been fully adopted yet.

Based on these comparisons of concrete dimensions, Polish municipalities use $\mathrm{PB}$ more extensively (more municipalities implemented $\mathrm{PB}$, higher participation, larger budget), but Slovak municipalities (except the case of Petržalka) have one advantage: they invite citizens to participate in all stages of $\mathrm{PB}$, from formulating the rules, through submitting and realizing their projects up to deciding and monitoring, which matches the idea of PB more closely. In that sense, HR and Pazin as the town with the most developed PB model in HR are more similar to Slovak municipalities. There are not many local units in HR applying PB, but in the case of Pazin the citizens are involved in all phases of the preparation of the local budget. 


\section{Conclusion}

The aim of the article was to provide a comparative analysis of the use and role of PB in Croatia, Poland and Slovakia and to identify which models of PB are used in these countries in order to identify the most suitable model of participatory budgeting for Eastern European countries.

The analysis of all Slovak municipalities and almost all Croatian and Polish municipalities that implemented PB in recent years was provided. The first part of the analysis of selected cases consisted of the history and origins of $\mathrm{PB}$, the organization of meetings, the type of deliberation, the position of civil society, the initiators and main actors, all of which helped us to identify the models that are used in selected countries. In PL and SVK "Porto Alegre adapted for Europe" prevails, but the "Representation of organized interests" model and the "Consultation on public finances" model are also represented. HR is somewhat different, since most of the local units have not developed their models of PB yet. There are some elements of the "Proximity participation" and the "Consultation of public finances" models, but the one in Pazin might be indicated as "Porto Alegre adapted for Europe". Since the concept of good governance includes the strengthening of accountability, transparency and the principle of legality, promoting meaningful participation and affecting the increase of public policies required by the needs of ordinary people (Santiso 2001), "Porto Alegre adapted for Europe" seems to be the most appropriate model for the contribution of $\mathrm{PB}$ processes to the quality of governance. The analysis in selected countries has confirmed that other PB models do not involve citizens in decision-making processes to an extent wide enough for the strengthening and development of indicated values.

The second part of the analysis focused on the amount of the budgets, the number of participants and projects and their outcomes. The main problems and challenges facing PB in all countries are also outlined. The problem or huge challenge is how to involve more citizens in $\mathrm{PB}$ processes, since the share of participating citizens who voted for the projects is not very high in Slovakia (between $0.5 \%$ and $8.43 \%$ ) and Croatia (between $0.77 \%$ and $6.8 \%$ ), while in Poland the relative indicators are better (5.15\%-24.1\%) but still rather low. Yet it is debatable whether voting for projects means active involvement of citizens, but at least it is a tool that increases the interest of citizens in public-services provision in terms of deciding on public spending. On the other hand, PB brings the possibility for active citizens to express themselves in the so-called co-creation in public services. The discussion indicates that PB can be seen as a tool for increasing citizens' involvement in analyzed countries, but so far to a low degree, and to raise this, the use of IT for on-line voting can be a solution (Poland has higher participation mostly thanks to on-line voting). 
Based on the analysis and facts stated in the discussion, it can be concluded that $\mathrm{PB}$ might be considered an innovative tool for managing public-services provision (all proposed projects must fulfil criteria of general benefit, and topics are from areas of public services), and it follows the trend of public-administration reforms and thus can help promoting the concept of good governance in the Eastern European countries.

On the other hand, a question to ask is what the costs of PB implementation are and whether the benefits of $\mathrm{PB}$ are higher than these costs. In this article mainly the benefits of $\mathrm{PB}$ processes are discussed, and to some extent the problems that municipalities need to challenge when implementing PB. However, very little is known about the expense side of this process. This could be a field of further research, complete with analyzing and measuring particular outcomes of $\mathrm{PB}$ and risks connected with the process.

\section{References}

Bovaird, Tony and Elke Löffler. 2003. "Quality Management in Public Sector Organizations." In Tony Bovaird and Elke Löffler (eds). Public Management and Governance. London/New York: Routledge, pp. 137-147.

Bovaird, Tony and Elke Löffler. 2002. "Moving from Excellence Models of Local Service Delivery to Benchmarking 'Good Local Governance." International Review of Administrative Sciences 68(1), 9-24.

City of Dabrow. 2014. "Przygotowanie procedury Dąbrowskiego Modelu Budżetu Partycypacyjnego.” Available at https://mac.gov.pl/dzialania/partycypacyjnybudzet/przygotowanie-procedury-dabrowskiego-modelu-budzetu-partycypacyjnego/ (last accessed 25 September 2014).

City of Poznań. 2014. "Rules for Participatory Budgeting in Poznań for 2015." Available at http://www.poznan.pl/mim/main/losowanie-czlonkow-zespoluopinujacego,p,15574,27284.html (last accessed 15 September 2014).

Dunleavy, Patrick, Helen Margetts, Simon Bastow and Jane Tinkler. 2006. "New Public Management Is Dead: Long Live Digital-Era Governance." Journal of Public Administration Research and Theory 16(3), 467-497.

Kębłowski, Wojciech. 2014. "Budżet partycypacyjny. Ewaluacja, Instytut Obywatelski, Warszawa 2014." Available at www.instytutobywatelski.pl/wp.../07/ budzet-partycypacyjny-web.pdf (last accessed 25 September 2015).

Klimovský, Daniel. 2010. “Genéza koncepcie good governance a jej kritické prehodnotenie v teoretickej perspektíve.” Ekonomický časopis 2, 188-205. 
Koprić, Ivan, Gordana Marčetić, Anamarija Musa, Vedran Đulabić, Vedran, and Goranka Lalić Novak. 2014. Upravna znanost: javna uprava u suvremenom europskom kontekstu, Zagreb: Pravni fakultet Sveučilišta u Zagrebu: Studijski centar za javnu upravu i javne financije.

Kozuń-Cieślak, G. 2013. "Efektywność inwestycji publicznych w kapitał ludzki." Ekonomista 3, 319-344.

Kraszewski, Dariusz and Karol Mojkowski. 2014. "Budżet obywatelski w Polsce, Fundacja im. Stefana Batorego, Warszawa: 2014." Available at http://www. maszglos.pl/wp-content/uploads/2014/03/Budzet-obywatelski-w-Polsce-D.Kraszewski-K.-Mojkowski.pdf (last accessed 18 August 2014).

Michalski, Grzegorz and Aleksander Mercik. 2011. "Liquid Assets Strategies in Silesian Non-Profit Organizations." Financial Management of Firms and Financial Institutions 2011, 258-270.

Nemec, Juraj, Beáta Mikušová Meričková and Zuzana Vozárová. 2012. “Management of Contracting Public Services and its Quality in Slovakia." NISPAcee Journal of Public Administration and Policy 5(1), 55-74.

Osborne, Stephen P. 2010. The New Public Governance?: Emerging Perspectives on the Theory and Practice of Public Governance. London and New York: Routlegde, $1-17$.

Osborne, Stephen P. 2006. “The New Public Governance?” Public Management Review 2006(3), 377-387.

Osborne, Stephen and Kerry Brown. 2005. Managing Change and Innovation in Public Service Organizations. London: Routledge.

Pierre, Jon and B. Guy Peters. 2005. Governing Complex Societies: Trajectories and Scenarios. Hampshire and New York: Palgrave Macmillan.

Pollitt, Christopher and Geert Bouckaert. 2011. Public Management Reform: A Comparative Analysis - New Public Management, Governance, and the NeoWeberian State. $3^{\text {rd }}$ edn. Oxford: University Press.

Resolution No. LXXIV-1337-2014 Rzeszów City Council, of 29 April 2014. Available at http://bip.erzeszow.pl/prawo-lokalne/uchwaly-rady-miasta-vi-kadencji/uchwaly-podjete-w-2014-roku/17073,uchwala-nr-lxxiv13372014 (last accessed 27 August 2015).

Rhodes, Roderick Arthur William. 1996. “The New Governance: Governing without Government." Political Studies 44, 652-667.

Santiso, Carlos. 2001. "International Co-operation for Democracy and Good Governance: Moving Towards a Second Generation?" The European Journal of Development Research 13(1), 154-180. 
Sintomer, Yves, Carsten Herzberg and Anja Röcke. 2008. "Participatory Budgeting in Europe: Potentials and Challenges." International Journal of Urban and Regional Research 32(1), 164-178.

Sześciło, Dawid. 2012. "Uwarunkowania prawne budżetu partycypacyjnego w Polsce." Finanse Komunalne 12/2012.

UN-HABITAT. 2004. 72 Frequently Asked Questions about Participatory Budgeting Quito: AH Editorial.

Vaceková, Gabriela. 2013. "Financial Controlling in Non-Profit Organizations: The Case of Slovak Republic." Risk Governance and Control: Financial Markets e Institutions 3(2), 49-57.

Wampler, Brian. 2013. “The Diffusion of Brazil's Participatory Budgeting: Should 'Best Practices' be Promoted?" Available at www.library.uniteddiversity. coop/Decision_Making_and_Democracy/AdoptingParticipatoryDemocracy.pdf (last accessed 25 September 2015). 